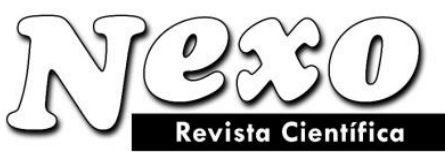

Vol. 34, No. 01, pp. 469-476/Marzo 2021

\title{
Mechanisms of e-commerce enterprises development in the context of digitalization
}

\section{Mecanismos de desarrollo de empresas de comercio electrónico en el contexto de la digitalización}

\author{
Svetlana Viktorovna Panasenko ${ }^{1, *}$, Vyacheslav Petrovich Cheglov ${ }^{1}$, Ibrahim Agaevich \\ Ramazanov $^{1}$, Elena Anatolevna Krasil'nikova ${ }^{1}$, Pavel Nikolaevich Sharonin ${ }^{2}$ \\ ${ }^{1}$ Plekhanov Russian University of Economics, Moscow, Russia. \\ ${ }^{2}$ Moscow Polytechnic University, Moscow, Russia. \\ *.v.panasenko@yandex.ru
}

(recibido/received: 01-December-2020; aceptado/accepted: 27-February-2021)

\begin{abstract}
The article deals with the development of a mechanism for the e-commerce enterprises' extension in the context of digitalization. It is established that e-commerce enterprises should actively implement the possibility of combining offline and online channels and consider ways to improve the operational efficiency of conducting activities through the automation of commodity accounting and analytical accounting systems, the development of loyalty programs, and acquiring including through the use of contactless payment technology. It is proved that digital trade enterprises need to actively implement selfservice cash registers and develop their own mobile applications. It is revealed that e-commerce enterprises should accumulate available information, analyze the frequency, place, time, and preferred channel of purchases, and form a point-based personalized offer. It is determined that digital transformation entails not only investment in new technologies and their subsequent implementation, but also the transformation of the product offered by the company in the market.
\end{abstract}

Keywords: mechanism, enterprise, e-commerce, digitalization, demand, supply, economy.

\section{RESUMEN}

El artículo trata sobre el desarrollo de un mecanismo de extensión de las empresas de comercio electrónico en el contexto de la digitalización. Se establece que las empresas de comercio electrónico deben implementar activamente la posibilidad de combinar canales fuera de línea y en línea y considerar formas de mejorar la eficiencia operativa de la realización de actividades a través de la automatización de la contabilidad de productos básicos y los sistemas de contabilidad analítica, el desarrollo de programas de lealtad y la adquisición de mediante el uso de tecnología de pago sin contacto. Está demostrado que las empresas de comercio digital necesitan implementar activamente cajas registradoras de autoservicio y desarrollar sus propias aplicaciones móviles. Se revela que las empresas de comercio electrónico deben acumular la información disponible, analizar la frecuencia, el lugar, el tiempo y el canal preferido de compras y formar una oferta personalizada basada en puntos. Se determina que la transformación digital 
conlleva no solo la inversión en nuevas tecnologías y su posterior implementación, sino también la transformación del producto que ofrece la empresa en el mercado.

Palabras clave: mecanismo, empresa, comercio electrónico, digitalización, demanda, oferta, economía.

\section{INTRODUCTION}

One of the priority conditions for the effective development of e-commerce enterprises in the Russian Federation in the context of digitalization of the economy is the analysis of current changes in its structure and functioning mechanisms, and on their basis, the definition of the conceptual foundations for the development of such enterprises. This approach allows solving comprehensively the problem of improving the activities of e-commerce enterprises and defining clearly the algorithms for its solution.

In this case, e-commerce is a highly intelligent field of activity. It includes practical solutions in the field of information law and digital money, technical and software support, information management and internet marketing, internet logistics, internet insurance, internet advertising and public relations, information security, and consulting, as well as internet banking and trading.

All this determines the specific development directions of e-commerce enterprises, especially in the context of the formation and development of international relations. At the same time, the list of these areas will be significantly expanded with the development and spread of e-commerce enterprises. Therefore, coordinating the efforts of state bodies and enterprises, organizations, and professional organizations, directly involved in such business to jointly develop scientific and practical recommendations and make optimal decisions, is currently of great importance.

The study of the digitalization issues of the economy is reflected in the works of S.I. Koroleva, V.I. Malyshkov, T.P. Gorelova (2017), I.I. Litsenberg (2018), S. Mikhnevich (2019), Ya.E. Pile (2019), A.Yu. Radakina (2017), E.N. Smirnov (2019), and others. At the same time, researchers pay considerable attention to the problems of development and improvement of the e-commerce management system. However, depending on the changing economic and social conditions, the approaches used to form development mechanisms of e-commerce enterprises in the context of digitalization should change and develop as well.

\section{METHODS}

The theoretical and methodological basis of the research included the abstract-logical method, methods of induction, deduction, analysis, synthesis, and systematization, used to justify the approach to the formation of development mechanisms of e-commerce enterprises in the context of digitalization.

The information base of the article included statistical data of state bodies, legislative and regulatory documents governing the functioning of e-commerce enterprises in the context of digitalization, approaches to regulating the system of interaction among the main participants of digital trade, as well as the results of scientific research (Agamirova et al., 2017; Ogloblina et al., 2020; Zavalko et al., 2017).

In the course of the study, it was planned to consider managing options for digital trade enterprises, justify the development directions of the management system to confirm its development parameters in the context of digitalization, as well as systematize the functions of the management system at e-commerce enterprises. 


\section{RESULTS}

The practice has shown that the main digital trade entities include buyers, private entrepreneurs, large enterprises, banks, etc. (Fig. 1).

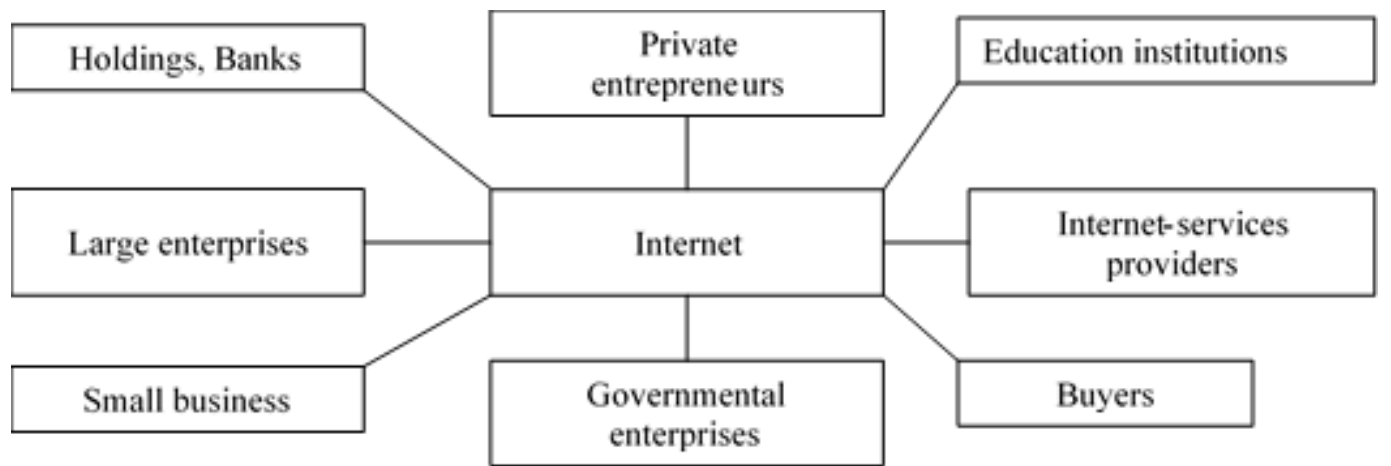

Figure 1. Digital trade entities

At the same time, in certain segments of industrial production in the Russian Federation, several conditions have already formed that favor commercial transactions among the main participants of digital trade. Individual companies of the metallurgical sector and agribusiness came closest to using digital solutions. In the future, one can expect that it is these sectors that will play the role of drivers in the development of international and intercorporate digital business.

Mechanical engineering, the chemical complex, and the food industry of the Russian Federation are less ready to use digital solutions. Their capabilities differ significantly depending on the specific subsector. In general, the prospects for the development of intercorporate and international e-commerce are mainly related to the possibility of further improvement of the macroeconomic situation, which can significantly reduce the impact of factors that hinder the effective implementation of e-commerce mechanisms among its participants.

In the foreseeable future, it is difficult to expect fundamental positive changes from the Russian economy that would be able to radically change the existing practice of relations between e-commerce participants. Besides, an avalanche of sales of industrial products via the Internet is unlikely in the very near future.

Currently, the full cycle of e-commerce, where all phases of the promotion of goods, works, and services, starting from the signing of a contract and ending with their payment, are almost never fully implemented in the Russian Federation. This means that within the framework of the digital model, digital trade participants still mainly use paper document flow in various transactions, while often using cash flow in online stores, which leads to the growth of shadow schemes in e-commerce.

Thus, the unique advantages of e-commerce, both for business and the end-user are not fully implemented. For example, electronic auctions, which operate intensively in many countries, are not widespread enough in the Russian Federation. Currently, single contracts are concluded using digital signatures, while in the digital sector, payment using a digital signature is almost non-existent.

This will also contribute to qualitative changes in the e-commerce sector, first in the corporate segment. Thus, only due to the high competition in the course of conducting electronic auctions on Russian electronic platforms, companies achieve a reduction in the cost of electronic procurement of products. The largest role in the field of e-commerce is played by business relations between large and medium-sized joint-stock companies that carry out the purchase and sale of goods and services through such trade. 
In this case, one can consider a single-window mechanism for e-commerce enterprises in the Russian Federation. Using the single-window mechanism, the process of providing and sharing the necessary information to meet regulatory requirements can be significantly simplified and facilitated for the benefit of cross-border trade participants. Information flows between enterprises around the world and their public authorities can be accelerated and simplified, and relevant data can be more effectively coordinated and exchanged between states.

Using such a system allows increasing the efficiency and effectiveness of official control measures and reducing costs for public authorities and participants in international e-commerce through the rational use of resources. A single window, providing systematic data collection, can improve the risk management process for control and enforcement purposes, which will allow increasing the security and efficiency of international trade procedures.

Besides, the implementation of an appropriate payment system can facilitate the payment of duties and other fees to public authorities and institutions. A single-window concept, providing its participants with up-to-date information on tariff rates and other regulatory and procedural requirements, can reduce the likelihood of errors and increase the level of compliance by digital trade participants with the established conditions. Thus, the main advantage for trade participants is that the single-window mechanism provides a single channel for the one-time provision of all necessary information and documentation simultaneously to all government agencies related to export, import, or transit operations.

The opportunities for simplification and rationalization provided by the single-window concept are of particular importance for the Russian Federation in the context of the growing requirements for standardization of data for international deliveries in the context of the global financial crisis. The ability to process data efficiently and quickly has now become one of the key factors for competitiveness in the market, especially in international supply chains, while trade enterprises should benefit from accelerating customs clearance and further obtaining permits for the shipment of goods.

Besides, increased predictability may further limit opportunities for corruption in both the public and private sectors. Therefore, the relevance of these issues will largely depend on the structure of a particular single-window mechanism, as well as on the nature and scope of its functions. Usually, the complexity of these issues increases in direct proportion to the convenience that a single-window concept provides.

Studies show that the directions of reforming the customs system, customs procedures simplification, and automation of customs should include:

- implementing the best international practices and law enforcement practices to simplify customs procedures for bona fide importers and exporters by introducing the institution of authorized economic operators to speed up customs control of goods and reduce the time of border crossing;

- increasing the level of trust on the part of e-business, introducing public control over the activities of customs authorities and combating the smuggling of goods;

- providing a sufficient list of benefits to e-commerce enterprises and significantly reducing the list of documents for customs clearance;

- automating procedures for customs clearance of goods, that is, excluding maximally the human factor in the implementation of customs procedures, as well as practicing widespread use of digital accounting and electronic document management, risk analysis, implementing a full post-audit; 
- developing and implementing an automated customs clearance system, which will ensure prompt processing of digital customs declarations, creating the possibility for automatic calculation of customs payments.

Studies show that the process of digitalization, making not only related industries dependent on each other but also the entire economy in general, is based on long-term strategies, and requires predictability in business activities, availability and completeness of the information. The free market turns from a tool for assessing demand and supply into a tool for forming demand itself: the consumer value of goods and services is increasingly created at the expense of the information component, which determines the same consumer value.

However, along with the study of the economic foundations of e-commerce, marketing strategies of enterprises presenting their goods and services via the Internet, relevant is the study of its advantages (Fig. 2).

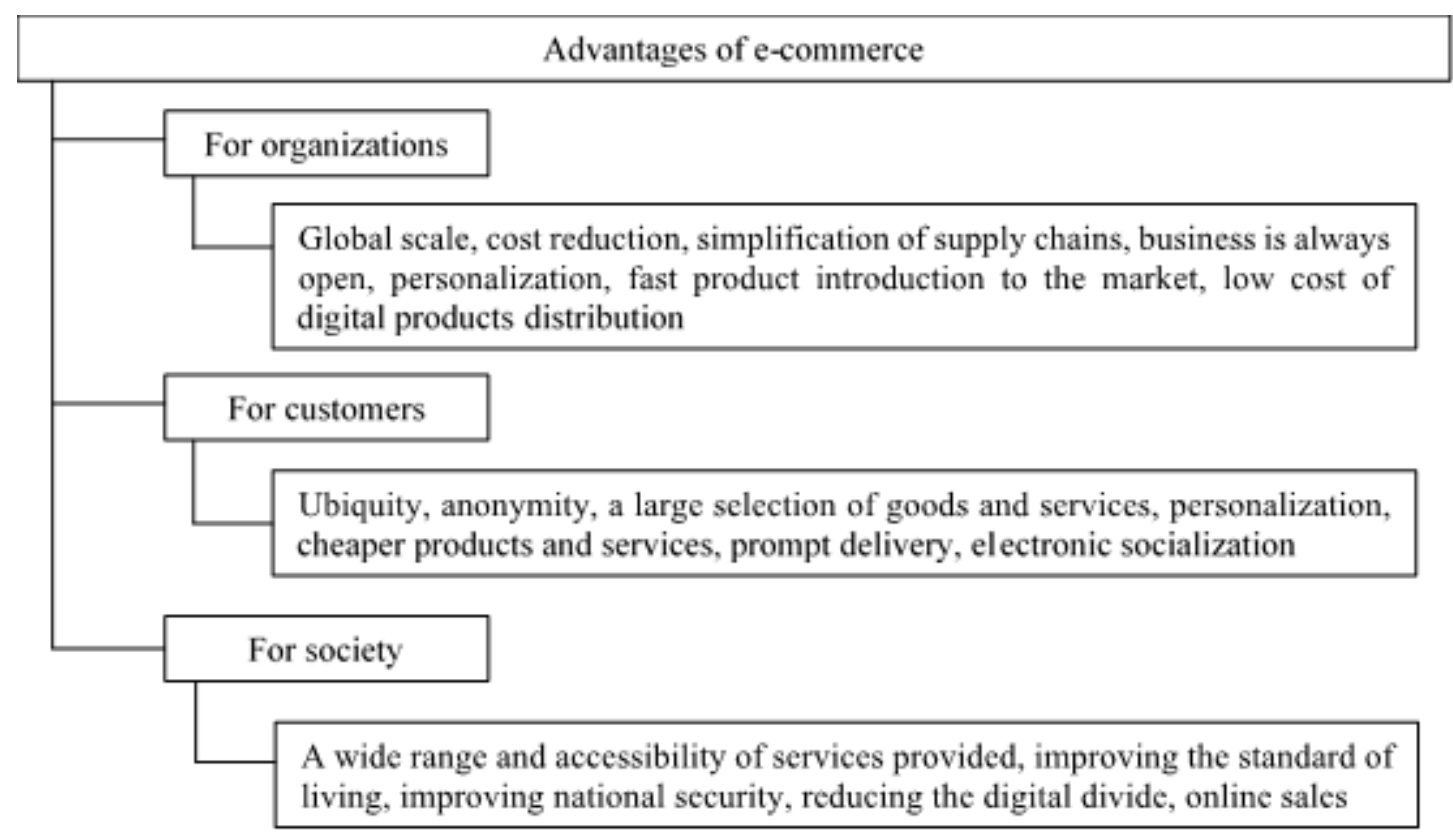

Figure 2. Advantages of electronic trade

The practice has shown that making a purchase online or using digital services (e-banking, health, education) is due to several universal motives, such as saving time; a wide range of opportunities, a variety of offers; usefulness, benefits; eliminating geographical and time barriers; and saving money. Besides, buyers in a crisis pay more attention to the price rather than the brand. However, even with growing consumer pessimism in the context of increasing crisis developments (the consumer confidence index continues to decline annually), the population prefers to spend money rather than to save.

This determines the importance of consumer demand, the consumer confidence index, and, accordingly, effective demand. In the course of the study, the authors have identified factors that affect the consumer confidence index. These include the average interest rate on loans, which, when increased, reduces the propensity of consumers to consume electronic services, as well as cash income per capita, whose growth increases the consumption.

One of the main drivers of economic growth in the Russian Federation is an increase in the level of consumer demand of the population. In particular, the income of the country's middle class in the context 
of the growing crisis should become the main investment resource. Therefore, it is important to develop an econometric model for predicting the level of demand for information services, including e-commerce, as well as to construct a consumer demand function and estimate the price elasticity of information services costs by total costs.

To analyze the impact of socio-economic processes on the purchasing power of the population, it is also important to study the elasticity of demand for economic growth and irregularities, which establishes a link between macroeconomic characteristics and demand. To do this, it is important to construct a consumer demand function and estimate the price elasticity of information services expenditures by total expenditures and income inequality.

Besides, it is necessary to assess the impact of growth and inequality on effective demand, as well as the impact of changes on average incomes and income inequality. For this purpose, changes in the level of demand for e-commerce services are proposed to be decomposed into two components - the elasticity of demand for economic growth and the system that determines the relationship between macroeconomic characteristics and demand.

At the same time, the level of demand for e-services depends on several factors, such as the development of information infrastructure, the level of well-being of the population, economic growth, inequality, and poverty in society. The factors affecting the level of service provision can be used in the development mechanism of enterprises engaged in e-commerce in the context of digitalization.

At the initial stage, it is necessary to select possible factors that affect the level of demand for e-commerce services. In this case, the dependent variables are the scope of services sold per consumer. The explanatory variables, in this case, are the gross regional product per capita, income per capita, and expenditure per capita.

\section{DISCUSSION}

The reliability of the presented approaches is confirmed by the fact that the demand for digital services is determined by a significantly large number of factors. Therefore, all factors cannot be taken into account due to several reasons. Some factors are not statistically measured at all, some factors were not measured at the beginning of the study period, and some input data cannot be compared (Bragin et al., 2019; Lukiyanchuk et al., 2020; Panasenko et al., 2019).

It should be noted that the current market situation and legislative initiatives cause resistance from some business representatives, however, digitalization continues penetrating the trading business, and company executives understand that compliance with current trends and the search for competitive advantages is the key to the success of a trading company in the market.

At the moment, the most popular technologies in trade are e-commerce development technologies, as well as applications that allow consumers to quickly and comfortably make purchases and the modernization of the network infrastructure. The most promising areas in which technological solutions are developed most successfully are network infrastructure modernization and the creation of solutions for the robotization of warehouses and cost reduction.

Among the obstacles to the active implementation of digital technologies in the activities of trading companies is the lack of a necessary budget, low profit, and instability of the economic environment, as well as low return on investment, and high risks. However, the increasing competition and changing reality in the digital sector encourage executives of trading companies to create conditions for the implementation of digital technologies and train staff to adapt to new business conditions. 
Consumer needs and purchasing behavior are also changing. Among the trends, the growing up of the younger generation of consumers focused on the digital environment can be noted, as well as their desire for a healthy lifestyle, introversion, and concern for the environment. In this case, the buyer is focused on personification, and thus the path to purchase becomes multichannel.

\section{CONCLUSION}

Summing up, it can be noted that e-commerce enterprises should actively implement the possibility of combining offline and online channels, and consider ways to improve the operational efficiency of conducting activities through the automation of commodity accounting and analytical accounting systems, the development of loyalty programs, and acquiring, including the use of contactless payment technologies. Such technologies will provide a unique experience to the buyer, regardless of the place of purchase and the method of receiving the goods.

Retail businesses need to actively implement self-service cash registers and develop their mobile applications. Understanding the value of the consumer, e-commerce enterprises should accumulate available information, analyze the frequency, place, time, and preferred channel of purchases, and practice personalized offerings. Besides, digital transformation entails not only investment in new technologies and their subsequent implementation, but also the transformation of the product or service offered by the company in the market, since it changes the perception and expectation of the consumer.

\section{ACKNOWLEDGMENTS}

The study was carried out within the framework of the state task of the Ministry of Science and Higher Education of the Russian Federation No. FSSW-2020-0009 "Development of a methodology for managing the competitiveness of enterprises in the field of commodity circulation in the context of the digital economy".

\section{REFERENCES}

Agamirova, Ek.V., Agamirova, El.V., Lebedeva, O.Ye., Lebedev, K.A., Ilkevich, S.V. (2017). Methodology of estimation of quality of tourist product. Quality - Access to Success, 18(157), 82-84.

Bragin, L.A., Panasenko, S.V., Nikishin, A.F., Aleksina, S.B., Boykova, A.V. (2019). Regional aspects of the development of the cheese market in terms of the trend of healthy nutrition. Entrepreneurship and Sustainability Issues, 7(1), 626-636.

Koroleva, S.I., Malyshkov, V.I., Gorelova, T.P. (2017). Rol' cifrovoj ekonomiki v sovremennoj torgovle [The role of the digital economy in contemporary trade]. Bulletin of the Academy, 3, 5-11.

Litsenberg, I.I. (2018). Osnovnye tendencii razvitiya torgovli v aspekte cifrovoj ekonomiki [Main trends in the development of trade in the context of the digital economy]. Bulletin of the Siberian University of Consumer Cooperation, 1(23), 3-8.

Lukiyanchuk, I.N., Panasenko, S.V., Kazantseva, S.Yu., Lebedev, K.A., Lebedeva, O.Ye. (2020). Development of online retailing logistics flows in a globalized digital economy. Revista Inclusiones, 7(S21), 407-416.

Mikhnevich, S. (2019). Tendencii mirovoj torgovli v kontekste cifrovoj globalizacii [World trade trends in the context of digital globalization]. Science and Innovation, 6(196), 64-68. 
Ogloblina, E.V., Seredina, M.I., Altunina, J.O., Kodolov, V.A. Lebedev, K.A. (2020). Socio-economic consequences of digital development of the economy. Revista Inclusiones, 7(Especial), 421-430.

Panasenko, S.V., Ramazanov, I.A., Karashchuk, O.S., Mayorova, E.A., Nikishin, A.F. (2019). Investigation into Russia's current level of self-sufficiency in grain. Scientific Papers. Series: Management, Economic Engineering and Rural Development, 19, 346.

Pile, Ya.E. (2019). Cifrovaya ekonomika: tochki rosta internet-torgovli [Digital economy: Growth points of Internet trade]. Economy: Yesterday, today, and tomorrow, 9(2-1), 126-135.

Radakina, A.Yu. (2017). Roznichnaya torgovlya v cifrovoj ekonomike [Retail trade in the digital economy]. Sciences Synergy, 17, 633-641.

Smirnov, E.N. (2019). Parametry razvitiya i regulirovaniya mezhdunarodnoj cifrovoj torgovli na sovremennom etape [The development and regulation parameters of international digital trade at the present stage]. E-Management, 2(1), 78-84.

Zavalko, N.A., Kozhina, V.O., Zhakevich, A.G., Matyunina, O.E., Lebedeva, O.Ye. (2017). Methodical approaches to rating the quality of financial control at the enterprise. Quality - Access to Success, 8(161), 69-72. 